NGTT Deel 54, Nommers $3 \& 4$, September en Desember 2013

Akper, Godwin, I

Stellenbosch University

\title{
Dialogue and an advocate of dialogue - Dirkie Smit on dialogue
}

\begin{abstract}
The essay explores Smit's thoughts on dialogue. In the first instance, the essay reflects on Smit's conviction on the need for dialogue in all human endeavours. Secondly, it explores Smit's (together with Leon Fouche) analysis of four dominant discussants on dialogue, namely Hans-Georg Gadamer, Jacques Derrida, Richard Rorty and Jürgen Habermas. What the essay sees as Smit's own idea of dialogue in relation to the four discussants is stated in the concluding part of the essay.
\end{abstract}

\section{INTRODUCTION}

This essay is written in honour of Dirk Jacobus Smit's sixtieth birthday. Smit has published over four hundred articles in scholarly journals of international repute. He has also written several books on a variety of topics. Many of Smit's former students are professors and lecturers themselves. It will be impossible to capture all of such a renowned theologian and scholar's work and life experiences in one essay. Instead, this essay attempts to explore some of Smit's thoughts on dialogue. First, it reflects on Smit's conviction of the need for dialogue in all human endeavours. This is followed by his exploration (together with Leon Fouché) of the views of four dominant participants in the discourse on dialogue, namely HansGeorg Gadamer, Jacques Derrida, Richard Rorty and Jürgen Habermas (Fouché and Smit 1996). The article ends with a brief discussion of what appears to be Smit's own position on dialogue in relation to the views of these four thinkers.

\section{DiRKIE SMIT ON THE NEED FOR DIALOGUE}

Postmodernity's emphasis is on "particularity" and "subjectivity" indirectly calls for plurality. But plurality and all its ramifications necessitate dialogue between groups and individuals, between traditions and disciplines; between religious groups and their adherents; between academic disciplines and those that specialise in them; et cetera. With dialogue, pluralism becomes a process that paves the way for communality - something especially cherished in African traditional circles. The different ideas, traditions, communities, theologies, hermeneutics, et cetera become vantage points for looking at the whole - the issue that forms the subject of conversation (the topic of the discussion). The merit of this process is that, by gaining "new insights", various groups come to realise that, even though they all have different perspectives on an issue, the issue itself is one. Therefore, although Smit respects and stresses the pluralistic nature of all theology, society and church traditions, he sees the different views, traditions and even denominations in conversation with each other. Stressing the pluralistic nature of theology, society and church traditions, Smit writes:

Christian theology - probably similar to law and economy - does not speak with one voice. Historically the dominant theological traditions - including the Orthodox, Catholic, and 
NGTT: Oopbron - http://ngtt.journals.ac.za

Protestant traditions - have developed different views concerning authoritative theological positions regarding theories and practices of social, economic or legal justice. All claims are therefore modest and contextual, and reflect specific traditions, experiences and perspectives (2005:225).

The conviction expressed above clearly shows Smit's support of the view that context gives more meaning to and brings closer to home an idea, tradition, theological position, and so on. Writing specifically on the shift from context to dialogue with particular reference to hermeneutics, Smit and Fouché state that contextuality "yielded an insight into the ethic of interpretation"1 among other things (Fouché and Smit 1996:79).

However, they argue that for long the emphasis, especially of contextual hermeneutics, has been on particularity, creating "awareness of power relations and their impact on responsibility and accountability of the interpretive acts" (Fouché and Smit 1996:79). This unavoidably puts almost too much emphasis on particularity - amongst others on particular contexts, persons, the com munity of interpretation and interpreters, and particular historical traditions - so that what one is left with is an emphasis on the "self" as a particular context and agent of interpretation and theologising. Therefore, we find, even within the same traditions including Orthodox, Catholic and Protestant traditions - different approaches to and ethics of both interpretation and theologising (cf. Smit 2005:225).

In view of the above situation, Smit calls for dialogue between contexts (contextual dialogue), between communities of interpretation (interpretive dialogue), between different church traditions (interdenominational dialogue), between theologians and sociologists, economists, philosophers, lawyers, educators, et cetera (interdisciplinary dialogue).

Despite his enthusiasm for dialogue, Smit is careful to note and address the ambiguity within the concept of dialogue itself. Therefore, he attempts, with a great degree of success, to give a dialogical description of dialogue between four distinguished scholars who wrote extensively on the subject, namely HansGeorg Gadamer, Jacques Derrida, Richard Rorty and Jürgen Habermas. The following sections follow Smit's concise exploration of their various positions on dialogue. His exposition is important as it will hopefully provide better insight into Smit's own position on dialogue. The first section explores Smit's conversation on dialogue with Gadamer.

\section{Dialogue ACCORDing to GADAMER}

Gadamer sees the "event of understanding as dialogue" (Fouché and Smit 1996:80; cf. Gadamer 1975:324-360 and 1972a:27-49; Vandenbulcke 1973:141-178). According to Smit, Gadamer did not use dialogue as the only metaphor to describe the event of understanding but in fact sees the so-called hermeneutic circle of understandinginterpretationapplication as one grand hermeneutical event. Hence, according to Gadamer, understanding is by its very nature a multifaceted event and dialogue forms an integral part of the event he calls understanding.

Furthermore, understanding is a process. This process encompasses "a fusion of horizons in which the horizon of the event to be understood comes to the fore as a single horizon and that changes the understanding and his or her [the dialogue partner's] horizon" (Fouché and Smit 1996:81; cf. Gadamer 1975:284-323). This means that all initial assumptions are "thwarted" as

1 All italics in quotations of Fouché and Smit are those of the authors. 
NGTT Deel 54, Nommers $3 \& 4$, September en Desember 2013

understanding takes place. The subversion of initial assumptions, coupled with new realisation facilitated by the process of understanding, then brings dialogue to the fore. For this to take place requires what Gadamer refers to as a "trusting goodwill", which to him is "a model for dialogue" (cf. Fouché and Smit 1996:81).

For this reason, Gadamer insists that "authentic dialogue takes place between an I and a you" (Gadamer 1975:340-345; cf. Fouché and Smit 1996:81). Therefore, dialogue takes place when there is an understanding between an I and a you, a willingness to listen to and to accommodate the other. In other words, this calls for - what Gerald West (1997) refers to as - a "transaction" between the I and the you (cf. West 1997 and 2002). It calls for the building of a culture of accommodation - or what Robert Vosloo (2004) would term - the cultivation of the habit of "hospitality". In other words, there has to be a deliberate attempt to develop "an attitude with which to enter into the dialogue if the dialogue is to be an authentic dialogue and not smothered or distorted or forced with hidden motives into a particular direction" (Fouché and Smit 1996:81), an attitude of respect towards the views and insights of the other. If this is not present, then there is no sustained dialogue or no dialogue at all. But what precisely is this attitude that is so necessary for authentic dialogue to take place? Smit and Fouché identify three kinds of approaches to dialogue in Gadamer's philosophy:

(i) An approach in which a particular behaviour is "derived" from human actions and, on the basis of this, a fixed expectation of the other is created. This implies a prediction on the part of the I of the you's behaviour, views and beliefs well in advance and deals with them on the basis of categories drawn up in advance (Fouché and Smit 1996:81). The authors categorically state that in this kind of dialogue the I imitating the you is precisely the "whole intention of Gadamer's philosophical hermeneutics", namely to dismiss it as "totally unattainable" (Fouché and Smit 1996:81).

(ii) An approach/attitude where I acknowledge you as a person, but not as a you that has any claims on me. In this attitude towards the you, his or her views are considered interesting to the extent that they are listened to. However, they have no impact on the I, and the latter's assumptions are not changed and influenced by supposedly new realisations and insights gained through information provided by the former. Also, there is no mutual impact between the two parties (cf. Fouché and Smit 1996:80-82; Gadamer 1975:324-360).

(iii) The third approach/attitude towards the you that Gadamer distinguished is one whereby the $\mathrm{I}$ is open to the you which has something to say to him or her. In this kind of dialogue there exists a mutual willingness, an openness to be addressed by the other (Fouché and Smit 1996:82). There is communication between the I and the you. The former is addressed by the latter - a kind of transaction then takes place between the two participants to the discussion. Both "open themselves to be addressed by and to the impact of what they are talking about" (Fouché and Smit 1996:82). However, "neither the I nor the you submit in any way to the other, but place themselves under the control and persuasive power of what is discussed" (Fouché and Smit 1996:82). For Gadamer this kind of dialogue "corresponds with an authentic hermeneutic experience" (cf. Fouché and Smit 1996:82). It constitutes authentic dialogue (Gadamer 1968:13-80). In this third kind of dialogue, what necessitates a willingness to open up to the other is the constant acknowledgement by the partners in the discussion that they "do not know". This the authors explain as follows: "The role of the question is to subvert fixed opinions in the open space of profession of meaning, so that the partners in the discussion respectfully know that they do not know" (Fouché and Smit 1996:82). They then 
NGTT: Oopbron - http://ngtt.journals.ac.za

summarise what constitutes authentic dialogue for Gadamer:

... for Gadamer authentic dialogue is thus possible only between participants in a dialogue who are prepared to listen to one another; who are willing to be told something by the other one; who have goodwill towards one another; who are prepared to give in and allow themselves to be persuaded by the power and legitimate claims of the relevant issue (die sache) (Fouché and Smit 1996:83).

Authentic dialogue is, therefore, not just an event; it is also a process of opening up to the other.

\section{Dialogue ACCORDING TO DERRIDA}

Smit and Fouché also explore Derrida's position on dialogue. They follow Derrida's description of dialogue as "suspicious dialogue in counterposition". Unlike Gadamer, for whom dialogue takes place in a living exchange between an I and a you, dialogue - according to Derrida takes place in a written text (Fouché and Smit 1996:84; cf. Derrida 1982:109-136). What is a written text? For Derrida "language is always already text" because the writer is "already a disrupted sign, infiltrated by absence" (Fouché and Smit 1996:84).

Derrida's scepticism towards authentic dialogue is further revealed by his insistence that it is "constantly impossible to decide which possibility is the true and authentic one" (Fouché and Smit 1996:84). Hence Caputo (1987:116-117 cited in Fouché and Smit 1996:84) likens the works of Gadamer, emphasising openness and willingness to be addressed by the other you to a rabbi, while that of Derrida, emphasising counterposition and never a position, is likened to a poet:

Gadamer is like a rabbi who conveys the truth of the ancient text respectfully and truthfully; Derrida is like a poet who sees the impossible possibilities in the text and caricatures it in a matter of associations (in Fouché and Smit 1996:84).

Gadamer assumed that one participates in dialogue in order to understand and to be understood. Hence his view of dialogue as an event that mutually benefits the I and the you engaged in the dialogue. Derrida always withdraws from this eagerness to engage in a dialogue by adopting a strategy of irony in which he wishes to overwhelm his discussion partner through a deliberate misunderstanding of the other (Fouché and Smit 1996:84). In this way, for Derrida, what actually ensues in dialogue is a counterposition to a position taken in a dialogue and, in his own view, it is this that gives meaning to the dialogue. Hence Derrida's attitude to dialogue is simply the second kind of attitude found in Gadamer's analysis of dialogue. Derrida is not influenced by information offered by the (other) you and insists that the $\mathrm{I}$ is absolute, so that the latter finds no possibility in the text of the (other) you.

However, Fouché and Smit - perhaps for the sake of dialogue - do identify some useful contributions that Derrida makes to the discussion on dialogue. They argue that

[i]t would be more appropriate to see that Derrida has a tempering function in the dialogue on dialogue which could lead to a fuller realization of what we are doing when we engage in a dialogue ... [Thus] ... Derrida's contribution to the dialogue on dialogue is to demonstrate that constructive contributions should not be taken too seriously, but with a pinch of salt. His subversive suspicion directed at the scaffolding does not lead to 
NGTT Deel 54, Nommers $3 \& 4$, September en Desember 2013

the joyful and mirthprovoking, and draws the marginalized being into the centre of the discussion (Fouché and Smit 1996:84, 85).

\section{RORTY'S IDEA OF DIALOGUE}

According to Fouché and Smit, Rorty examines dialogue as therapy that changes our vocabulary. This is because Rorty

... characterizes the tendency of Western thought as a search for foundations, a striving for the ideals of objectivity, rationality and truth. His intention is to show that these ideals are unattainable. He does this by proposing a better system of thinking which, according to him, could liberate these thinkers from enslavement to "unattainable ideals" (Fouché and Smit 1996:85).

Rorty's intention, according to the authors, is therapeutic and interestingly characterises dialogue partners as "excessively serious and plagued by unnecessarily hang-ups and afflicted by the unfortunate tendency to scratch where it doesn't itch" (Fouché and Smit 1996:85).

For Rorty the better way is to accept "the contingency of existence" which makes it meaningful for one to search for the truth. Both truth and objectivity are relative in Rorty's view. Dialogue is the best way of achieving solidarity with the society in which one lives (Fouché and Smit 1996:86). In fact, dialogue is strictly participation in discussion within society. It is dialogue between people whose path through life have fallen together united by civility rather that by common goal, much less by common ground (Rorty 1980:318 cited in Fouché and Smit 1996:86).

Dialogue is, therefore, not a mutual understanding impacting on the I and the you as in Gadamer's view. It is almost an empty exercise devoid of set goals, but it is nevertheless important for society, and the I that is engaged in dialogue with that society. Fouché and Smit (1996:87) locate the importance of dialogue in Rorty's intention "to free people from fundamental thinking for the sake of a new vocabulary, a new way of learning, so that they may become new people."

\section{HABERMAS' VIEW OF DIALOGUE}

Smit and Fouché's discussion of Habermas' concept of dialogue as noncoercive dialogue according to rational procedures shows that, for Habermas, dialogue is necessitated by his appeal to rationalism (Fouché and Smit 1996:87). For Habermas "ideology criticism should take place through rationalisation". This is because of his understanding that rationalisation "will lead to a better, more human, life in society" (1996:87). This is also because of Habermas' deep conviction that only a society built on rationality and not supposedly on "false democracy" - the latter being, more often than not, a product of manipulation - is an ideal society (Smit 2007:17, cf. Habermas 1962). But for ideology critique to take place through rationalisation there has to be dialogue and true democratisation. The latter occurs in a context where everyone affected is really and fully informed, empowered and in the position to take part in a rational discussion, and not in a false democracy as it is found in political systems all over (Habermas in Fouché and Smit 1996:87).

True democracy is linked to, what Habermas calls, noncoercive dialogue. Noncoercive dialogue, the so-called ideal speechsituation, is found where "an open, free and informed 
NGTT: Oopbron - http://ngtt.journals.ac.za

discussion in which no partner has the power to force or influence the other into accepting ideas" exists (Fouché and Smit 1996:87). Therefore, Habermas distinguishes his own idea of rationality from those popular in the society. Smit reports that Habermas does this in his Knowledge and Human Interest (German edition 1968). Habermas' kind of rationality is the one understood as "interhuman conversation and debate, the kind of rationality that is intended to promote ideals of freedom and liberation, humanness and dignity" (Smit 2007:17). In this sense, Habermas' idea of dialogue is similar to Gadamer's description of the third approach to dialogue with the other, where there is a willingness to be informed by and to listen to the other.

\section{SMIT'S PARADIGM OF DIALOGUE}

For the purpose of dialogue itself, Smit and Fouché do not choose Gadamer, Derrida, Rorty or Habermas' paradigms of dialogue as having any comparative advantage over the others. At the end of their detailed discussion of these four views of dialogue, they expressly state:

Perhaps it would be best, in line with a typical postmodernist approach or simply in line with Paul Celan's words - "wahr sprichtwer Schatten spricht", not to choose between these alternatives, but to juggle them in the awareness of the abundance of possibilities! Different metaphors, including dialogue, function in different ways in different historical situations. What may be more suitable in one situation, may be problematic in another (Fouché and Smit 1996:135; cf. Celan 1975:135).

One finds, therefore, with Smit and Fouché a deliberate and conscious attempt to understand and to be informed by, to be in conversation with (cf. Tracy 1981 and 1987), the partners in the dialogue. In the view of the authors, the emphasis on contextuality, on particularity, however important, must be complemented by a move towards the other, respecting the otherness, the strangeness, the particularity, and legitimate claims, of the other. And perhaps this is what dialogue proper should be (Fouché and Smit 1996:90). This perhaps informed their decision not to choose between the four alternative paradigms of dialogue they discussed.

However, like the American theologian David Tracy (1990) whom Smit very often cites, Smit's position is closer to Gadamer's third approach to dialogue. Like Gadamer, Smit emphasises the importance of respecting the otherness, strangeness and particularity of the apparent legitimate claims of the other. When this takes place there is mutual understanding and influence that impact on all the partners in dialogue - a position towards which Rorty and Derrida are not favourably disposed. While Rorty calls for, what Smit describes as, "empty dialogue" - saying that there is nothing outside of the dialogue that can support it or guide it or guarantee anything - Derrida is sceptical about the legitimacy of truth claims made by the other you.

In any case, Smit's attempt at a dialogue between the four alternative views on dialogue he does by searching for a perspectival view of the four alternatives rather than by looking at them as mutually exclusive. By "juggling" the four paradigms one is likely to end up with a variety of possible approaches to dialogue that can be applicable in different situations and contexts. This is again close to Gadamer's third approach to dialogue where there is a willingness to listen to and to be informed by the other. Like Gadamer, Smit sees the wisdom of listening to the views of Rorty, Derrida and Habermas, though he seems to part ways with some aspects of relativism in their analyses of what dialogue is and should be. In many of his works Smit favours 
NGTT Deel 54, Nommers 3 \& 4, September en Desember 2013

dialogue between positions, persons, traditions, contexts, communities, disciplines, et cetera, rather than making a biased selection of seemingly alternate positions and traditions. For example, in a discussion of the Barmen Declaration and the Belhar Confession, Smit states that "[t]he Belhar Confession is the product of a conversation with the Barmen Declaration. Without Barmen there would have been no Belhar in its present form" (2006:291 - my emphasis - GIA; Cf. also Smit 1982, 1998a, 1998b, 2001, 2005). With this statement, in the case of Barmen and Belhar, Smit underscores the importance of conversation, of dialogue and of the willingness to listen to the other as that did and will open up new possibilities that otherwise would have been impossible. When Smit elaborates on how Barmen should be listened to today, he argues that it is important to read Barmen not as six separate and distant theses - precisely as it is true of Belhar - of which we can adhere to some while ignoring and neglecting others. Only in their joint claim do they confess what is truly at stake. Therefore, the informed structure, the overall thrust of Barmen is of extreme importance (Smit 2006:293).

\section{CONCLUSION}

Dirkie Smit's appreciation of dialogue does not come at the cost of an under estimation of the reality of the ambiguity and the pluralistic nature of academy, church and society (cf. Tracy 1981 and 1987). As was seen at the beginning of this essay, Smit admits, in commenting on the pluralistic nature of contemporary theological discourse, that "Christian theology ... does not speak with one voice" (2005:225). However, Smit acknowledges that the genius of dialogue lies exactly in the possibility that conversation creates between a plurality of views, ideas, possibilities, traditions, theologies, hermeneutical methods, philosophies, church doctrines, ethical approaches, as well as between different approaches to dialogue itself. Hence Smit's idea of dialogue is not a call for hegemonic views, opinions, methods, persons, traditions et cetera. He does not call for a choice between paradigms or for the adoption of a single approach to an issue such as dialogue. Rather, Smit thinks that various perspectives on an issue, together with its discussants, should speak to each other and that they should be listened to as a way of learning from each other. In this sense Smit comes close to Gadamer's (third) approach to dialogue. Smit succeeds in advocating authentic dialogue while upholding the reality of a plurality of views, societies, traditions, hermeneutics, communities, ideologies, et cetera. Therefore, he also listens to Rorty, Derrida and Habermas even though their concepts of dialogue are quite different from his own.

\section{BIBLIOGRAPHY}

Caputo, J. D. 1987. Radical Hermeneutics. Bloomington, IN: Indiana University Press.

Celan, P. 1975. Gedichte, I. Frankfurt: Suhrkamp.

Derrida, J. 1982. The Ends of Man. In Derrida, J. Margins of Philosophy, tr. and notes Bass, A. Chicago, IL: University of Chicago Press, 109-136.

Fouché, H. L. and Smit D. J. 1996. Initiating a Dialogue on “Dialogue". Scriptura (57), 79-102.

Gadamer, HG. 1968. Platos Dialektische Ethik Philosophie. Hamburg: Felix Meiner.

Gadamer, HG. 1972. Platons Ungeschriebene Dialektik. H-G Gadamer Kleine Schriften 111. Tübingen: J.C.B. Mohr, 27-49.

Gadamer, HG. 1975. Wahrheit und Methode. (Truth and Method.) Tübingen: J.C.B. Mohr Paul Sierbeck.

Rorty, R. 1980. Philosophy and the Mirror of Nature. Princeton, NJ: Princeton University Press.

Smit, D. J. 1998a. Biblical Hermeneutics: The First 19 Centuries. In Konig, A. and Maimela, S. (eds.), Initiation into Theology: The Rich Variety of Theology and Hermeneutics. Pretoria: Van Schaik, 275-296.

Smit, D. J. 1998b. Biblical Hermeneutics: The 20th Century. In Konig, A. and Maimela, S. (eds.), Initiation into Theology, 297-317. 
NGTT: Oopbron - http://ngtt.journals.ac.za

Smit, D. J. 2001. Rhetoric and Ethic? A Theological Perspective on the Politics of Reading the Bible.

Paper delivered during a consultation with the Center of Theological Inquiry (Princeton Theological Seminary, NJ) on Reformed Exegesis and Ecumenicity held at Stellenbosch University, 30 March to 3 April 2001.

Smit, D. J. 2005. On Social and Economic Justice in South Africa: a Theological Perspective on Theoretical Paradigms. In Van der Walt, A. J. (ed.), Theories of Social and Economic Justice. Stellenbosch: Sun Press, 225-238.

Smit, D. J. 2006. Barmen and Belhar in Conversation - A South African Perspective. NGTT (47), 291-301.

Smit, D. J. 2007 What Does "Public" Mean? Questions with a View to Public Theology. In Hansen, L. (ed.), Christian in Public: Aims, Methodologies and Issues in Public Theology. Stellenbosch: Sun Press, 11-46.

Tracy, D. W. 1981. The Analogical Imagination: Christian Theology and the Culture of Pluralism. London: SCM.

Tracy, D. W. 1987. Plurality and Ambiguity, Hermeneutics, Religion, Hope. San Francisco, CA: Harper and Row.

Tracy, D. W. 1990. Dialogue With the Other: The Inter-Religious Dialogue. Leuven: Peeters. Vandenbulcke, J. 1973. Hans-Georg Gadamer: Een Filosofie van het Interpreteren. (HansGeorg Gadamer: A Philosophy of Interpretation.) Brugge: Orion, Nv Descleé de Brower.

West, G. O. 1997. On the Eve of African Biblical Scholarship. Trajectories and Trends. Journal of Theology for Southern Africa (99), 99-115.

Vosloo, R. R. 2004. Identity, Otherness and the Triune God: Theological Groundwork for a Christian Ethic of Hospitality. Journal of Theology for Southern Africa (119), 69-89.

\section{KEY TERMS}

Dialogue/

Dirkie Smit

Jacques Derrida

Hans-Georg Gadamer

Jürgen Habermas

\section{SLEUTELWOORDE}

Dialoog

Dirkie Smit

Jacques Derrida

Hans-Georg Gadamer

Jürgen Habermas

Dr. Godwin I Akper

14-16, Ahmadu Bello Way,

Victoria Island

Lagos

NIGERIA

igodwin@nou.edu.ng 